\title{
Effect of rheology and processing parameters on the EPD coatings of basic sol-gel particulate sol
}

\author{
Y. CASTRO, B. FERRARI, A. DURÁN, R. MORENO* \\ Instituto de Cerámica y Vidrio (CSIC), Campus de Cantoblanco, c/Kelsen s/n 28049, \\ Madrid, Spain \\ E-mail: rmoreno@icv.csic.es
}

\begin{abstract}
Homogeneous thick silica coatings were prepared onto metals substrates by Electrophoretic Deposition (EPD) using particulate sol-gel sols. The synthesis of the sols was performed by mixing tetraethoxysilane and methyltriethoxysilane under basic catalysis. The synthesis, storage and processing conditions were optimised, correlating the rheological properties of the sols with EPD performance and reliability. Homogeneous and crack-free coatings are obtained when both, the synthesis and the deposition, are performed under tight conditions avoiding the contact with room humidity. The maximum crack-free thickness of the sintered coatings was $12 \mu \mathrm{m}$, three times more than those obtained by dipping. (c) 2004 Kluwer Academic Publishers
\end{abstract}

\section{Introduction}

Sol-gel processing has demonstrated to be an effective route for producing glass-like coatings on metals that improve their resistance under corrosive environments [1]. However, the glass-like coatings obtained from hybrid sols by mechanical methods, as dipping, spinning or spraying, have a small critical thickness $(<2 \mu \mathrm{m})[2,3]$ and hence, much effort is being devoted to increase the attainable thickness. One way to obtain thicker coatings is by adding colloidal particles to the precursor solution [4]. Another way, valid only for particulate systems, is to force migration of particles by an external electric field, i.e., by electrophoretic deposition (EPD) $[5,6]$.

Most of the work reported in the literature concerning EPD of sol-gel systems deals with the synthesis of colloidal particles by the sol-gel method and their further dispersion in a solvent, usually ethanol [7]. Sometimes, a commercial suspension of colloidal particles is used [8]. In both cases, the formation of a ceramic film involves the deposition of the particles and the solid-state sintering at temperatures typically higher than $800^{\circ} \mathrm{C}$.

On the other hand, the production of glass-like coatings is substantially different: in this case, hybrid organic-inorganic solutions are prepared in acid solgel catalysis, and colloidal particles are incorporated to the sol. The suspensions are deposited by EPD and high density is reached by low-temperature treatments $\left(\leq 500^{\circ} \mathrm{C}\right)$ [9]. In such case, the alkoxide chains of the sol form the structural network entrapping the colloidal particles.

However, precursor solutions can also be catalysed under basic conditions. When using a base catalyst, the fast condensation rates provoked by the nucleophilic attack lead to the formation of a particulate sol that behaves as a suspension of dense particles [10].

Previous work has demonstrated the suitability of EPD to produce thick sol-gel coatings on metals by using either acid-catalysed solutions containing colloidal particles or basic-catalysed solutions themselves $[11,12]$.

The aim of the present work is to study the stability of a basic-catalysed sol and to optimise the parameters involved in the preparation of thick coatings by EPD. For this purpose, the rheological properties of the particulate sols and the EPD parameters are optimised.

\section{Experimental}

The particulate sols were prepared by mixing tetraethoxysilane (TEOS) and methyltriethoxysilane (MTES) with $\mathrm{NaOH}$ as catalyst according to the procedure patented by Jonschker et al. [10]. After $\mathrm{NaOH}$ addition, deionized water was incorporated drop by drop to prevent the sol gelation. The molar ratio $\mathrm{H}_{2} \mathrm{O} /$ alkoxides varied between 1.1 and 1.3 and the final $\mathrm{pH}$ of the sol was 9-10, to reach a concentration, expressed as $\mathrm{SiO}_{2}$ of $267 \mathrm{~g} / \mathrm{l}$. This sol was diluted with absolute ethanol to a concentration of $188 \mathrm{~g} / \mathrm{l}$. The effect of the synthesis conditions on the stability was studied by preparing the sols in open flasks and also under reflux and with $\mathrm{N}_{2}$ flow, in order to avoid contact with atmospheric humidity.

The stability of the starting and the diluted sol was studied by rheological measurements at different testing conditions. A rotational rheometer (Haake RS50, Germany) was used under controlled rate conditions from 0 to $1500 \mathrm{~s}^{-1}$. Viscosity curves of 267 and $188 \mathrm{~g} / \mathrm{l}$ sols were measured at 25 and $5^{\circ} \mathrm{C}$ as prepared and after 


\section{ELECTROPHORETIC DEPOSITION: FUNDAMENTALS AND APPLICATIONS}

one hour left in open atmosphere. The influence of storage conditions on the stability was evaluated for $188 \mathrm{~g} / \mathrm{l}$ sols, prepared under controlled synthesis conditions and maintained at $5^{\circ} \mathrm{C}$.

Glass and stainless steel AISI 304 substrates were used for dipping tests, performed at withdrawal rates ranging from 10 to $53 \mathrm{~cm} / \mathrm{min}$. EPD tests were carried out on AISI 304. Glass substrates were cleaned in an ultrasonic bath with ethanol during $15 \mathrm{~min}$, and stainless steel by using an alkaline solution (P3Emalan5668: P3Emalan0469, Miele, Germany) for $5 \mathrm{~min}$.

EPD tests were performed using a power source (AMEL 551, UK) in galvanostatic conditions to avoid the fall down of the electric field during the tests. Graphite sheets were used as counter-electrode. After deposition, the substrates were extracted at a constant withdrawal rate of $10 \mathrm{~cm} / \mathrm{min}$, to distinguish the contribution of EPD to the total coating thickness.

EPD tests were conducted on 267 and $188 \mathrm{~g} / 1$ sols by changing the current density from 0.2 to $1.5 \mathrm{~mA} / \mathrm{cm}^{2}$ for deposition times of $5 \mathrm{~min}$ at $5^{\circ} \mathrm{C}$ in open and tight conditions. Tight conditions were preserved using a tight electrophoresis cell maintaining $5^{\circ} \mathrm{C}$ and nitrogen flow. To evaluate the effect of EPD on the suspension stability, the viscosity of the particulate sols was measured before and after EPD tests.

The kinetics of the EPD process was studied for the $188 \mathrm{~g} / \mathrm{l}$ sol as a function of the molar ratio water/alkoxides and ageing. In all cases the evolution of the potential was registered during the tests.

The deposits were sintered at $500^{\circ} \mathrm{C}$ for $30 \mathrm{~min}$ in air and characterised by scanning electron microscopy (Zeiss DSM-950, Germany). The thickness coatings was measured by profilometry (Talystep, Taylor-Hobson, UK) on glass substrates and gravimetry for EPD onto SS.

\section{Results and discussion}

The rheological behaviour of particulate sols prepared via basic catalysis was studied considering the influence of temperature and concentration. Fig. 1 shows the viscosity curves measured after $1 \mathrm{~h}$ storage in open atmosphere of the starting $267 \mathrm{~g} / \mathrm{l} \mathrm{sol}$ at 25 and $5^{\circ} \mathrm{C}$. The fresh concentrated sol was nearly Newtonian and had a rather low viscosity (16 $\mathrm{mPa} \cdot \mathrm{s})$, but when maintained in open conditions for only $1 \mathrm{~h}$ the viscosity strongly increased up to $150 \mathrm{mPa} \cdot \mathrm{s}$, losing the Newtonian behaviour and becoming largely thixotropic. When the same starting

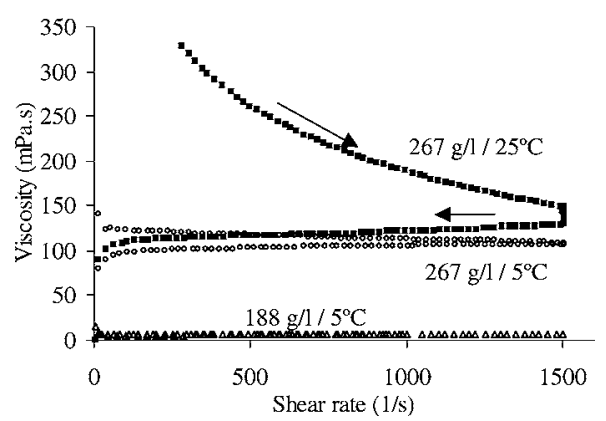

Figure 1 Evolution of viscosity with shear rate for $267 \mathrm{~g} / 1$ sol at 25 and $5^{\circ} \mathrm{C}$ and for $188 \mathrm{~g} / \mathrm{l} \mathrm{sol}$ at $5^{\circ} \mathrm{C}$ after $1 \mathrm{~h}$ in open atmosphere. sol is maintained at $5^{\circ} \mathrm{C}$ for $1 \mathrm{~h}$, the viscosity still increases up to $\sim 100 \mathrm{mPa} \cdot \mathrm{s}$ although the thixotropy practically disappears and a nearly Newtonian behaviour is maintained. This demonstrates the low stability of the basic sols, which improves by reducing storage temperature (e.g., $5^{\circ} \mathrm{C}$ ).

In order to increase the stability, the concentrated sol was diluted with ethanol to $188 \mathrm{~g} / \mathrm{l}$. Fig. 1 shows also the viscosity curve for the $188 \mathrm{~g} / 1$ particulate sol maintained at $5^{\circ} \mathrm{C}$. On diluting, the viscosity decreases down to $6 \mathrm{mPa} \cdot \mathrm{s}$ and is maintained constant after $1 \mathrm{~h}$ in open atmosphere. These results indicate that basic sols must be diluted to achieve sufficient stability to be used for a forming process as EPD.

Further improvement of stability is achieved by avoiding the contact with atmosphere. Long exposures to humid atmosphere could promote the sol gelation, accelerating the hydrolysis and condensation rates, by reaction with room humidity $(\mathrm{RH})$. Consequently, particulate sols were tightly synthesised under reflux and with nitrogen flow and further diluted with ethanol to a concentration of $188 \mathrm{~g} / \mathrm{l}$. The stability of these $188 \mathrm{~g} / \mathrm{l}$ sols was evaluated by measuring the viscosity at different times. Fig. 2 compares the evolution of viscosity against time of $188 \mathrm{~g} / \mathrm{l}$ sols stored at $5^{\circ} \mathrm{C}$ with and without atmospheric contact. The sol maintained in contact with atmosphere loses the stability after $8 \mathrm{~h}$, while that stored in closed conditions maintains stable for at least 4 days.

Coatings were first prepared by dipping onto glass substrates using particulate sols with silica concentrations of 267 and $188 \mathrm{~g} / \mathrm{l}$. Fig. 3 shows the thickness of the dipping coatings as a function of the withdrawal

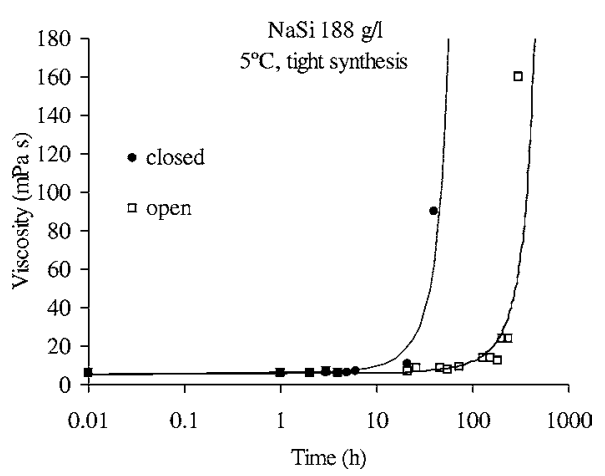

Figure 2 Evolution of the viscosity vs. time for $188 \mathrm{~g} / 1$ sols prepared in tight conditions at $5^{\circ} \mathrm{C}$ and stored in open and closed flasks at $5^{\circ} \mathrm{C}$.

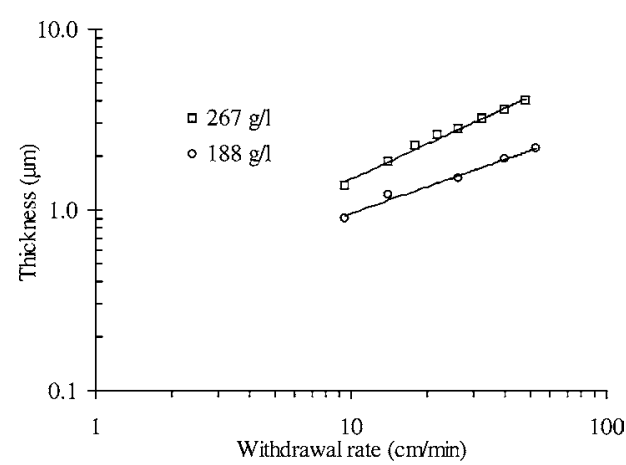

Figure 3 Evolution of the dipping thickness with the withdrawal rate for 267 and $188 \mathrm{~g} / \mathrm{l}$ sols. 


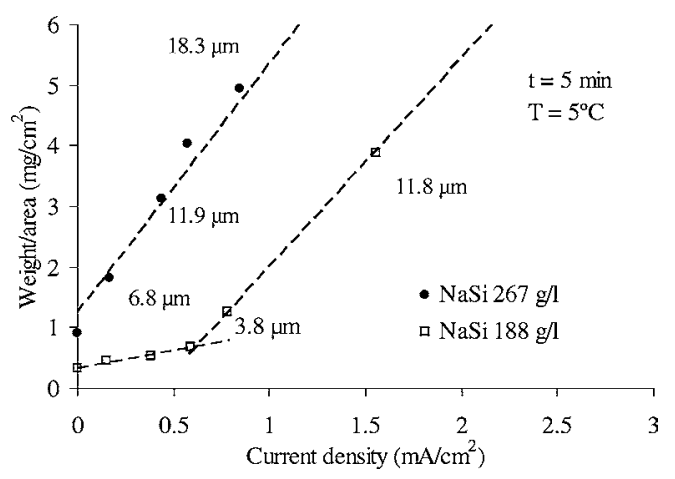

Figure 4 Evolution of weight per unit area with the current density for 267 and $188 \mathrm{~g} / \mathrm{l}$ sols deposited using an open cell at $5^{\circ} \mathrm{C}$.

rate. The concentrated sol was used to determine the maximum attainable thickness for this composition. The critical thickness, defined as the maximum thickness without cracks, could not be reached in this system. A maximum thickness of $4.3 \mu \mathrm{m}$ was obtained for the $267 \mathrm{~g} / \mathrm{l} \mathrm{sol}$ at a withdrawal rate of $53 \mathrm{~cm} / \mathrm{min}$, but the coatings present large border effects and defects. The maximum thickness of a homogeneous film was $3.5 \mu \mathrm{m}$, obtained at a withdrawal rate of $40 \mathrm{~cm} / \mathrm{min}$.

EPD tests were performed for both 267 and $188 \mathrm{~g} / \mathrm{l}$ sols, prepared in open conditions and maintained at $5^{\circ} \mathrm{C}$ during the test. Fig. 4 shows the evolution of the weight per unit area with the current density for constant deposition times of $5 \mathrm{~min}$. It can be observed that the deposited mass follows linearity with the current density for the $267 \mathrm{~g} / \mathrm{l} \mathrm{sol}$, whereas for the $188 \mathrm{~g} / \mathrm{l} \mathrm{sol}$, the deposit weight varies linearly up to $0.5 \mathrm{~mA} / \mathrm{cm}^{2}$, where the slope sharply increases.

To evaluate the effect of the deposition process in open cell on the suspensions, a rheological characterisation of the sols was performed before and after successive EPD tests. Fig. 5a and b show the viscosity curves of the concentrated sol just before EPD (fresh sol) and after being used for several EPD tests for around $20 \mathrm{~min}$. Similarly, Fig. 5c and d show the viscosity curves for
$188 \mathrm{~g} / \mathrm{l}$ sols, as prepared and after $25 \mathrm{~min}$ of EPD test. Both sols were maintained in an open cell during electrophoresis. The viscosity of the concentrated sol increases from below $16 \mathrm{mPa} \cdot \mathrm{s}$ to above $30 \mathrm{mPa} \cdot \mathrm{s}$ after EPD, and a significant thixotropy appears. The same occurs for the $188 \mathrm{~g} / \mathrm{l} \mathrm{sol}$, the viscosity increasing from $6 \mathrm{mPa} \cdot \mathrm{s}$ to $9 \mathrm{mPa} \cdot \mathrm{s}$

From these results it can be stated that the sol degrades when performing the EPD tests in an open cell, strongly changing the deposition conditions. To avoid this effect, a tight electrophoresis cell was designed to perform the deposition preserving the sol from $\mathrm{RH}$ contact. Fig. 6 compares the deposition kinetics of the same sol $(188 \mathrm{~g} / \mathrm{l})$ subjected to a current density of $0.6 \mathrm{~mA} / \mathrm{cm}^{2}$ for tests performed in open and tight cells at $5^{\circ} \mathrm{C}$. In the open cell a change of slope is observed after $25 \mathrm{~min}$, while in the tight cell the linearity is maintained, but the deposition kinetics is much slower. This demonstrates that $\mathrm{RH}$ has a strong influence on the sol stability and also on the deposition kinetics.

The effect of the ratio water/alkoxides was studied with the aim of accelerating the deposition kinetics. Three slightly different water/alkoxides ratios (1.13, 1.18 and 1.23 ) were considered to prepare $188 \mathrm{~g} / \mathrm{l}$ sols in tight conditions. Fig. 7 shows the EPD kinetics for these sols. Viscosity slightly increases with the water/alkoxides ratio, ranging from 4.2 to $4.8 \mathrm{mPa} \cdot \mathrm{s}$, and the sol structure evolves to a higher crosslinking degree. Homogeneous, crack-free deposits of $20 \mu \mathrm{m}$ were obtained after $25 \mathrm{~min}$ EPD for the highest water/alkoxides ratio (e.g., 1.23). The sols with intermediate ratio, 1.18, needed $\sim 1 \mathrm{~h}$ to reach this thickness, and the sols with the lowest ratio, 1.13, result in a too slow deposition kinetics. The amount of water used for the sol synthesis determines the growing kinetics of the deposit, that is, its thickness, although homogeneous deposits can be obtained in all cases.

The following was to study the effect of ageing. For this purpose, one batch of the $188 \mathrm{~g} / \mathrm{l}$ sol was prepared, divided in three parts and stored at $5^{\circ} \mathrm{C}$ in open
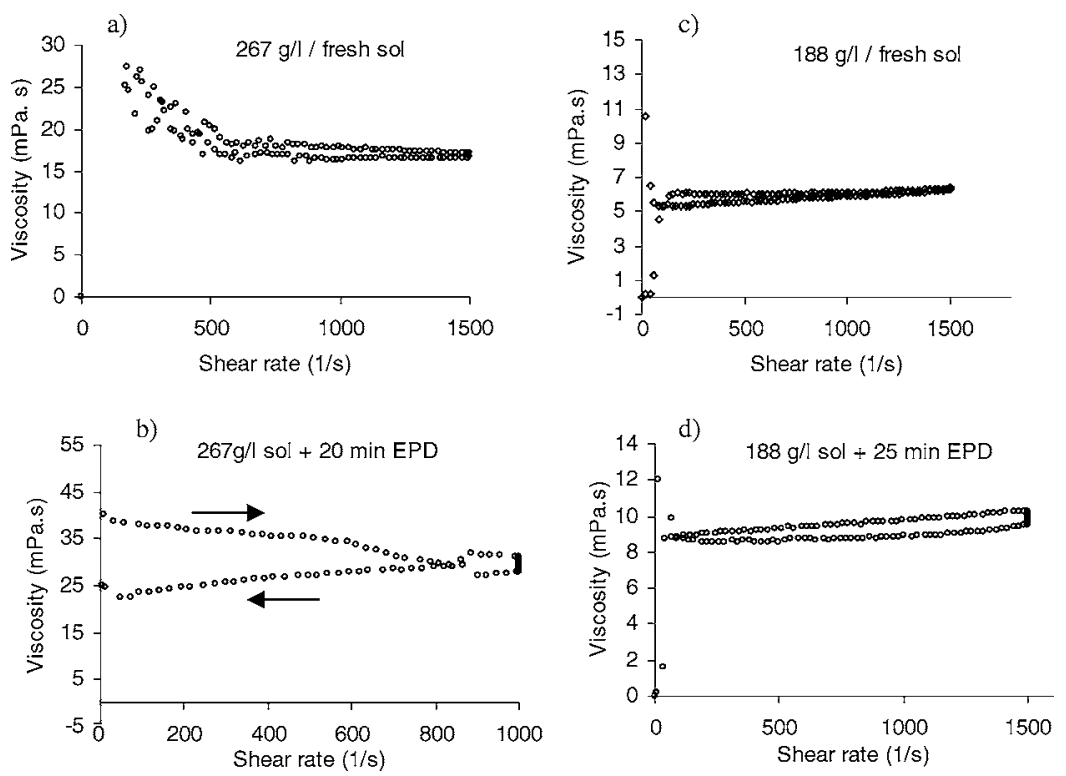

Figure 5 Evolution of the viscosity with the shear rate for the $267 \mathrm{~g} / \mathrm{l}$ sol as prepared (a), and after 20 min of EPD tests (b); and for the $188 \mathrm{~g} / \mathrm{l}$ sol as prepared (c), and after 25 min of EPD tests (d). 


\section{ELECTROPHORETIC DEPOSITION: FUNDAMENTALS AND APPLICATIONS}

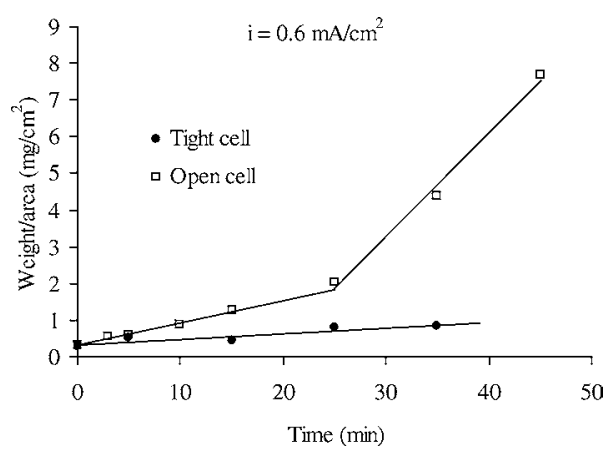

Figure 6 EPD kinetics of $188 \mathrm{~g} / 1$ sols at current density $0.6 \mathrm{~mA} / \mathrm{cm}^{2}$ using open and tight electrophoresis cells.

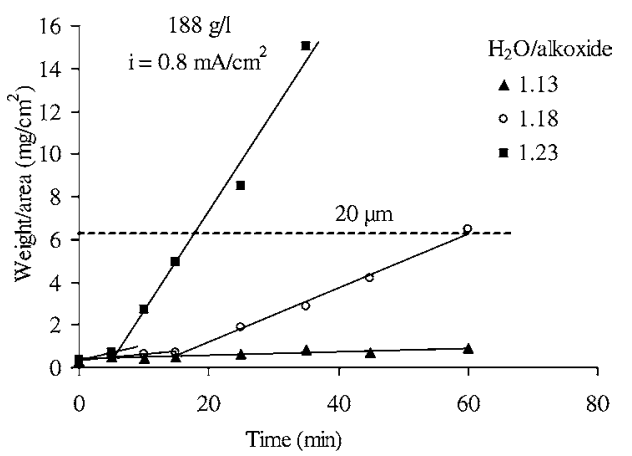

Figure 7 Evolution of the weight per unit area with deposition time for $188 \mathrm{~g} / \mathrm{l}$ sols with different water/alkoxides ratios in tight electrophoresis cell at $5^{\circ} \mathrm{C}$

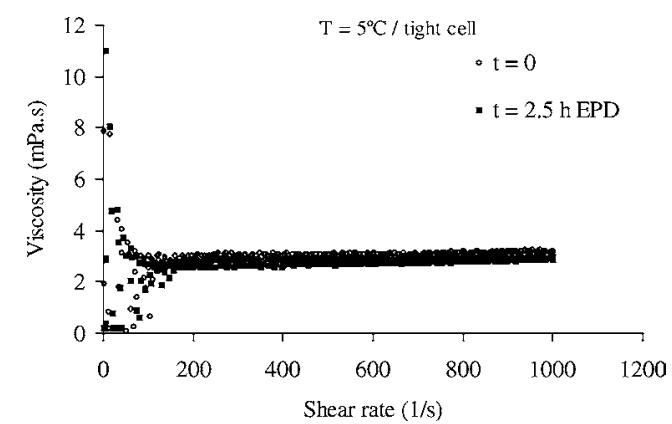

Figure 8 Evolution of the viscosity with the shear rate for the fresh $188 \mathrm{~g} / \mathrm{l} \mathrm{sol}(t=0)$, and after $2.5 \mathrm{~h}$ of EPD tests using tight electrophoresis cell.

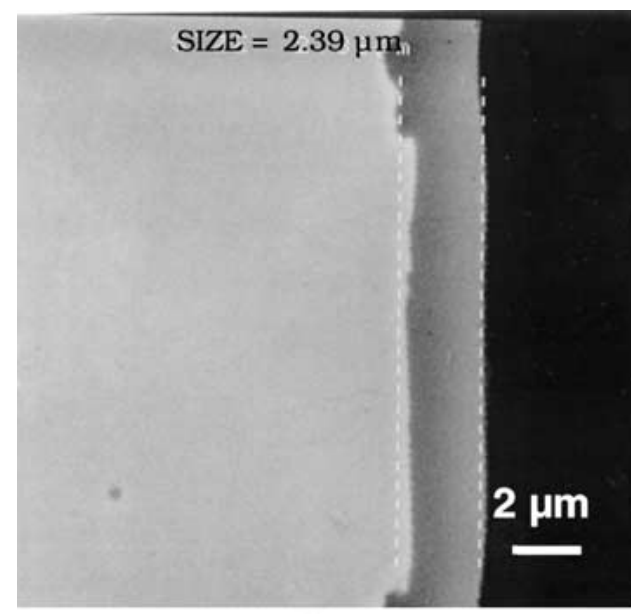

(a)
TABLE I Thickness of the deposits obtained by dipping and EPD as a function of sol ageing

\begin{tabular}{llll}
\hline $\begin{array}{l}\text { Ageing } \\
\text { time }(\mathrm{h})\end{array}$ & $\begin{array}{l}\text { Viscosity } \\
(\mathrm{mPa} \cdot \mathrm{s})\end{array}$ & $\begin{array}{l}\text { Dipping thickness } \\
(\mu \mathrm{m}) v=10 \mathrm{~cm} / \mathrm{min}\end{array}$ & $\begin{array}{l}\text { EPD maximum crack-free } \\
\text { deposits }(\mu \mathrm{m})\end{array}$ \\
\hline Fresh & 4 & 0.75 & 20 \\
14 & 13 & 1.28 & $<13$ \\
23 & 23 & 1.9 & $<10$ \\
\hline
\end{tabular}

atmosphere for different times up to reach the viscosity values shown in Table I, which relates the ageing parameters of the sol with the thickness of the coatings obtained by dipping (at $10 \mathrm{~cm} / \mathrm{min}$ ) and the maximum crack-free thickness of the films obtained by EPD. Dipcoating thickness increases with viscosity as expected, but no ageing effects have been detected on the coating quality.

The evolution of the coatings obtained by EPD was studied for the sols with different viscosities during the first 5 min of deposition. This set of tests was performed under potentiostatic conditions at a potential of $11 \mathrm{~V}$, because the conductivity changes with sol ageing (ranging from 340 to $465 \mu \mathrm{S} / \mathrm{cm}$ ) and short deposition times are applied. The EPD kinetics increases with increasing viscosity, but crack-free deposit thinner than 13 or $10 \mu \mathrm{m}$ (depending on viscosity) are reached after drying, while homogeneous and crack-free dry deposits of $20 \mu \mathrm{m}$ are obtained when fresh sols are used, see Fig. 7.

The $188 \mathrm{~g} / \mathrm{l}$ sol with the highest viscosity (23 mPa.s) was diluted with ethanol to reduce the viscosity to $4 \mathrm{mPa} \cdot \mathrm{s}$. However, the viscosity raised after only $1 \mathrm{~h}$, demonstrating that the sol ageing is an irreversible process.

Finally, after determining the best conditions for synthesis, storage and EPD processing, the evolution of the sols viscosity was evaluated during EPD in tight electrophoresis cell using a water/alkoxides ratio 1.18. Fig. 8 shows the rheological behaviour of the optimised sol maintained at $5^{\circ} \mathrm{C}$ before EPD tests and after $2.5 \mathrm{~h}$ of being subjected to successive EPD tests in the tight cell. Now, in contrast with the behaviour observed in Fig. 5 for EPD in open cell, the viscosity curves overlap perfectly, thus demonstrating that the macroscopic properties of the particulate sol are not perturbed by

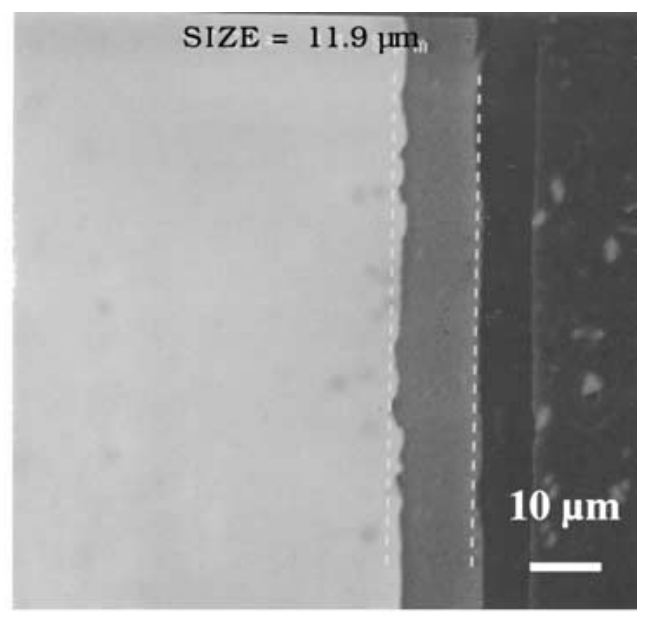

(b)

Figure 9 SEM microphotographs of coatings sintered to $500^{\circ} \mathrm{C}$ obtained by applying $2 \mathrm{~mA} / \mathrm{cm}^{2}$ during 2 min (a), and 5 min (b). 
the action of an electric field when contact with atmospheric environment is avoided.

After sintering, it was possible to obtain homogeneous, crack-free coatings of around $12 \mu \mathrm{m}$, near three times the maximum thickness attainable by a dipping process, from a $188 \mathrm{~g} / 1$ sol. Fig. 9 shows the SEM microphotographs of coatings obtained applying a current density of $2 \mathrm{~mA} / \mathrm{cm}^{2}$ for deposition times of 2 and 5 min, with thickness measured by SEM of 2.4 and $11.9 \mu \mathrm{m}$, respectively.

\section{Conclusions}

This work demonstrates that the rheological behaviour of particulate sols has a crucial role on the EPD processing, affecting not only the EPD kinetics, but also the quality and maximum thickness of the obtained coatings.

Particulate sol-gel sols prepared in basic catalysis strongly depend on the synthesis, storage and processing conditions. The stability of the sols may be enhanced by synthesising in tight conditions and further diluting with ethanol. The rheological behaviour is also affected by storage conditions. Better control of viscosity and improved stability have been reached by maintaining the sol under $5^{\circ} \mathrm{C}$ in closed flasks.

The water content has a direct influence on the viscosity, since the sols continuously evolve simply by contact with room humidity. Thus, it is necessary to accurately control the water/alkoxides ratio in the synthesis and to maintain it during the EPD process by using tight electrophoresis cells.

Ageing promotes an irreversible increase of viscosity that negatively affects the quality and maximum crackfree thickness of the EPD deposits.

When the sol is prepared in tight conditions and processed using a tight electrophoresis cell at $5^{\circ} \mathrm{C}$ the viscosity does not change, demonstrating that the macroscopic properties of the sol are not affected by the action of an electric field.

After sintering to $500^{\circ} \mathrm{C}$, homogeneous and crack-free coatings of $12 \mu \mathrm{m}$ have been obtained by EPD, three times thicker than those obtained by dipping.

\section{Acknowledgments}

This work has been supported by projects MAT2000-0952-C02-01 (CICYT, Spain) and EC BRITE Programme (BE97-5111) in collaboration with INM (Germany), Miele (Germany), Corus (The Netherlands), Ferro (France) and ABB (France). Dr. Mennig and Dr. Niegisch (INM) are gratefully acknowledged for sol processing.

Dr. Ferrari acknowledges CSIC and European Social Fund their support.

\section{References}

1. P. GAlliano, J. J. DE DAMBOREnEA, M. J. PASCUAL and A. DURÁn, J. Sol-Gel Sci. Techn. 13 (1998) 723.

2. P. INNOCENZI and P. F. JAMES, ibid. 3 (1994) 47.

3. M. APARICIO, M. A. Villegas and A. DURÁn, Bol. Soc. Esp. Ceram. Vidr. 36 (1997) 119.

4. H. J. SCHMIDT, G. JONSCHKER, S. GOEDICKE and M. MENNING, J. Sol-Gel Sci. Techn. 19 (2000) 39.

5. O. O. VAN DER BIEST and L. J. VANDEPERRE, Annu. Rev. Mater. Sci. 29 (1999) 327.

6. P. SARKAR and P. S. NiChOlson, J. Am. Ceram. Soc. 79 (1987) 2002.

7. D. E. CLARK, W. J. DALZELL and D. C. FOLZ, Ceram. Eng. Sci. Proc. 9 (1988) 1111.

8. K. HISHIDA, M. TATSUMISAGO and T. MINAMI, J. Ceram. Soc. Jap. 102 (1994) 334

9. Y. CASTRO, B. FERRARI, R. MORENO and A. DURÁN, J. Sol-Gel Sci. Tech. 23 (2002) 187.

10. G. JONSCHKER, M. MENNIG and H. SCHMIDT, European Patent no. EP0973958 (1998).

11. B. FERRARI, Y. CASTRO, J. GALLARDO, R. MORENO and A. DURÁN, Spanish Patent no. P200008525 (2000).

12. Y. CASTRO, B. FERRARI, R. MORENO and A. DURÁN, Adv. Mater. 14 (2002) 505.

Received 27 January

and accepted 30 June 2003 